\title{
Class of Antiretroviral Drugs and the Risk of Myocardial Infarction
}

\author{
The DAD Study Group*
}

\author{
ABSTRACT
}

\section{BACKGROUND}

We have previously demonstrated an association between combination antiretroviral therapy and the risk of myocardial infarction. It is not clear whether this association differs according to the class of antiretroviral drugs. We conducted a study to investigate the association of cumulative exposure to protease inhibitors and nonnucleoside reverse-transcriptase inhibitors with the risk of myocardial infarction.

\section{METHODS}

We analyzed data collected through February 2005 from our prospective observational study of 23,437 patients infected with the human immunodeficiency virus. The incidence rates of myocardial infarction during the follow-up period were calculated, and the associations between myocardial infarction and exposure to protease inhibitors or nonnucleoside reverse-transcriptase inhibitors were determined.

\section{RESULTS}

Three hundred forty-five patients had a myocardial infarction during 94,469 personyears of observation. The incidence of myocardial infarction increased from 1.53 per 1000 person-years in those not exposed to protease inhibitors to 6.01 per 1000 person-years in those exposed to protease inhibitors for more than 6 years. After adjustment for exposure to the other drug class and established cardiovascular risk factors (excluding lipid levels), the relative rate of myocardial infarction per year of protease-inhibitor exposure was 1.16 (95\% confidence interval [CI], 1.10 to 1.23), whereas the relative rate per year of exposure to nonnucleoside reverse-transcriptase inhibitors was 1.05 ( $95 \%$ CI, 0.98 to 1.13). Adjustment for serum lipid levels further reduced the effect of exposure to each drug class to 1.10 (95\% CI, 1.04 to 1.18) and 1.00 (95\% CI, 0.93 to 1.09), respectively.

\section{CONCLUSIONS}

Increased exposure to protease inhibitors is associated with an increased risk of myocardial infarction, which is partly explained by dyslipidemia. We found no evidence of such an association for nonnucleoside reverse-transcriptase inhibitors; however, the number of person-years of observation for exposure to this class of drug was less than that for exposure to protease inhibitors.

The members of the writing committee (Nina Friis-Møller, M.D., Ph.D., University of Copenhagen, Copenhagen; Peter Reiss, M.D., Ph.D., Academic Medical Center, Amsterdam; Caroline A. Sabin, Ph.D., Royal Free and University College, London; Rainer Weber, M.D., University Hospital Zurich, Zurich, Switzerland; Antonella d'Arminio Monforte, M.D., D.M.Sc., University of Milan, Milan; Wafaa El-Sadr, M.D., M.P.H., Columbia University, Harlem Hospital, New York; Rodolphe Thiébaut, M.D., Ph.D., INSERM E0338 and U593, Victor Segalen-Bordeaux 2 University, Bordeaux, France; Stephane De Wit, M.D., Ph.D., Centre Hospitalier Universitaire Saint-Pierre, Brussels; Ole Kirk, M.D., D.M.Sc., University of Copenhagen, Copenhagen; Eric Fontas, M.D., Centre Hospitalier Universitaire, Nice, Hôpital de l'Archet, Nice, France; Matthew G. Law, Ph.D., National Centre in HIV Epidemiology and Clinical Research, Sydney; Andrew Phillips, Ph.D., Royal Free and University College, London; and Jens D. Lundgren, M.D., D.M.Sc., University of Copenhagen, Copenhagen) of the DAD Study Group assume responsibility for the overall content and integrity of the article. Address reprint requests to Dr. Lundgren at the Copenhagen HIV Program, Faculty of Health Sciences, University of Copenhagen, Panum Institute, Blegdamsvej 3, 2200 Copenhagen N, Denmark, or at jdl@cphiv.dk.

*The members of the Data Collection on Adverse Events of Anti-HIV Drugs (DAD) Study Group are listed in the Appendix.

N Engl J Med 2007;356:1723-35

Copyright (C) 2007 Massachusetts Medical Society. 
OMBINATION ANTIRETROVIRAL THERapy has had a dramatic effect in reducing morbidity and mortality associated with human immunodeficiency virus type 1 (HIV-1) infection. ${ }^{1-4}$ However, concern has been raised regarding the effect of such therapy on the risk of coronary heart disease. Previous findings from the Data Collection on Adverse Events of Anti-HIV Drugs (DAD) study indicated that the incidence of myocardial infarction increased with longer exposure to combination antiretroviral therapy. ${ }^{5}$

A central question is whether this observed risk is attributable to all antiretroviral drugs or only to specific drugs. Although previous studies have reported a relationship between proteaseinhibitor use and cardiovascular disease, ${ }^{6-8}$ there are few data on the risk associated with nonnucleoside reverse-transcriptase inhibitors. Assessment of the role of specific drug classes is complicated by the fact that patients often switch components of their treatment because of the availability of newer drugs, the occurrence of adverse events, or failure of their regimens. ${ }^{9-11}$

There have been 3 years of follow-up of patients in the DAD study since the initial report. ${ }^{5}$ The additional data have made it possible to investigate the independent relationships between the risk of myocardial infarction and exposure to protease inhibitors and nonnucleoside reversetranscriptase inhibitors.

\section{METHODS}

\section{STUDY DESIGN}

DAD is an international collaboration of 11 cohorts of investigators following 23,437 HIV-1infected subjects at 188 clinics in 21 countries in Europe, the United States, and Australia. Details of the methods have been reported previously. ${ }^{5,12}$ Patients were followed prospectively during their regular visits to outpatient clinics. All participants were under active follow-up in their cohorts at the time of enrollment in the study (from December 1999 through April 2001). Data on sociodemographic features, clinical findings, treatment (antiretroviral and other medications received both before and after enrollment), and laboratory results were collected at enrollment and at least every 8 months thereafter with the use of standardized forms. All information was transformed into a standardized format and merged into a central data set annually. Institutional review board approval for the study and written informed consent from the study participants were obtained for each cohort individually, according to national and local regulations.

\section{OUTCOMES}

All incident cases of myocardial infarction were reported to the study coordinating office for validation and coding. ${ }^{5}$ Cases of myocardial infarction were categorized as definite, possible, or unclassifiable (e.g., sudden death in persons with no known terminal condition) and as fatal or nonfatal according to criteria applied in the World Health Organization Multinational Monitoring of Trends and Determinants in Cardiovascular Disease (MONICA) Study. ${ }^{13,14}$ Event validation and coding were performed without knowledge of the antiretroviral-treatment history of a patient.

\section{STATISTICAL ANALYSIS}

The DAD Steering Committee specified in 1999 that analyses assessing the risk of myocardial infarction according to antiretroviral-drug class would be performed once sufficient events had accumulated to permit such analyses. Details of the analytic approach have been described previously. ${ }^{5}$ Patients were followed prospectively from enrollment in DAD to the date of the first myocardial infarction, the date of death, 6 months after the patient's last clinic visit, or February 1, 2005, whichever occurred first. Each patient's follow-up period was divided into consecutive 1-month periods, and the patient's cumulative exposure to therapy at the start of each period was calculated (including exposure to treatment before enrollment). This information was used to assign the patient-month (and any events that occurred during that month) to the appropriate exposure category. All analyses were based on the first myocardial infarction that occurred during follow-up. All P values are two-sided, and no adjustment was made for multiple testing.

Poisson regression models (GENMOD procedure, SAS software, version 8) were used to quantify the relationship between exposure to each drug class and the incidence of myocardial infarction. First, we reassessed the association with any combination antiretroviral therapy (i.e., a regimen of more than one antiretroviral drug, including at least one protease inhibitor, at least one nonnucleoside reverse-transcriptase inhibitor, or both). The cumulative exposure to combination anti- 
retroviral therapy was categorized as no exposure, less than 1 year, 1 to 2 years, 2 to 3 years, 3 to 4 years, 4 to 5 years, 5 to 6 years, 6 to 7 years, and more than 7 years and was incorporated as a continuous variable in subsequent analyses.

We then considered the unadjusted relationship between the incidence of myocardial infarction and cumulative exposure to protease inhibitors and nonnucleoside reverse-transcriptase inhibitors. The primary Poisson regression models were then adjusted for demographic factors, calendar year, and conventional risk factors for cardiovascular disease. Specific categories were generated for missing data (e.g., unknown family history) to ensure that all patients and observed events were included. In addition, in sensitivity analyses, we considered the relationships with cumulative exposure to either drug class after exclusion of patients exposed to the other drug class.

In additional analyses, we assessed the role of established risk factors for myocardial infarction that may potentially be influenced by antiretroviral therapy, including diabetes or hypertension and the time-updated levels of serum lipids (total cholesterol, high-density lipoprotein [HDL] cholesterol, and triglycerides [ $\log _{2}$-transformed]). Lipid measurements were included regardless of fasting status. We also assessed the influence of markers of HIV-1 infection (CD4+ lymphocyte count nadir and peak HIV-1 RNA level).

\section{RESULTS}

\section{PATIENT CHARACTERISTICS AND FOLLOW-UP}

The DAD study cohort included 23,437 patients (Table 1). The median age at enrollment was 39 years (interquartile range, 34 to 45 ), and $24.1 \%$ of the patients were female. Among the $61.0 \%$ of patients for whom information on race or ethnic background (ascertained by different methods in different centers) was available, $77.9 \%$ were white, $16.9 \%$ were black, $3.3 \%$ were Hispanic, $1.9 \%$ were Asian, and $0.1 \%$ (nine patients) were classified as "other." The median nadir CD4+ lymphocyte count before enrollment was 200 cells per cubic millimeter (range, 1 to 2580 ), and $26.4 \%$ of patients had received a clinical diagnosis of the acquired immunodeficiency syndrome (AIDS). At enrollment, $60.8 \%$ of participants were current or former smokers, 3.1\% had diabetes, $14.4 \%$ had hypertension, and $42.0 \%$ had dyslipidemia.

The total follow-up in this analysis was 94,469 person-years, with a median of 4.5 years per patient. By the end of follow-up, 1518 patients (6.5\%) had died. The average annual rate of loss to followup, excluding deaths, was less than $3 \%$.

\section{EXPOSURE TO ANTIRETROVIRAL THERAPY}

By the end of follow-up, $93.6 \%$ of the patients had been exposed to some form of antiretroviral therapy, totaling 150,775 person-years of exposure, with a median exposure of 6.9 years (Table 1 ). Of all the patients, $79.4 \%$ had been exposed to protease inhibitors for a median of 4.0 years, and $63.7 \%$ had been exposed to nonnucleoside reversetranscriptase inhibitors for a median of 2.6 years. There was a total of 72,846 person-years of exposure to protease inhibitors (including 41,297 person-years of exposure to ritonavir-containing regimens) and 52,457 person-years of exposure to nonnucleoside reverse-transcriptase inhibitors.

\section{MYOCARDIAL INFARCTION}

Three hundred forty-five patients had a fatal or nonfatal myocardial infarction (incidence, 3.65 per 1000 person-years) (Table 1). Of these, $62.6 \%$ were definite, $22.6 \%$ were possible, and $14.8 \%$ were unclassifiable; $29.3 \%$ were fatal. By the time of the event, $90.4 \%$ of patients who had a myocardial infarction had been exposed to protease inhibitors (median exposure, 3.7 years), and $60.9 \%$ had been exposed to nonnucleoside reverse-transcriptase inhibitors (median exposure, 2.1 years).

\section{ASSOCIATION OF ANTIRETROVIRAL THERAPY WITH THE RISK OF MYOCARDIAL INFARCTION}

We confirmed our previous observation that increased exposure to combination antiretroviral therapy was associated with an increased risk of myocardial infarction (adjusted relative rate, 1.16 per year of exposure; 95\% confidence interval [CI], 1.09 to 1.23 ) (Fig. 1). The therapy-attributed relative rate did not differ significantly between men (relative rate, 1.13) and women (relative rate, 1.36; $P$ value for interaction $=0.40$ ) or between older patients ( $\geq 45$ years of age for men, and $\geq 55$ years of age for women; relative rate, 1.15) and younger patients (relative rate, 1.16; P value for interaction $=0.19$ ).

The incidence of myocardial infarction increased with increasing length of exposure to either class of drugs (Fig. 2A and Table 2, unadjusted model); for example, the incidence increased from 1.53 per 1000 person-years among those not 


\begin{tabular}{|c|c|c|c|c|}
\hline \multirow[t]{2}{*}{ Characteristic } & \multicolumn{2}{|c|}{ Baseline } & \multicolumn{2}{|c|}{ Last Follow-up } \\
\hline & $\begin{array}{l}\text { All Patients } \\
(\mathrm{N}=23,437)\end{array}$ & $\begin{array}{l}\text { Patients Who Had } \\
\text { a Myocardial } \\
\text { Infarction during } \\
\text { the Study } \\
(\mathrm{N}=345)\end{array}$ & $\begin{array}{l}\text { All Patients } \\
(\mathrm{N}=23,437)\end{array}$ & $\begin{array}{l}\text { Patients Who Had } \\
\text { a Myocardial } \\
\text { Infarction during } \\
\text { the Study } \\
(\mathrm{N}=345)\end{array}$ \\
\hline \multicolumn{5}{|l|}{ Demographic characteristics } \\
\hline Female sex — no. (\%) & $5649(24.1)$ & $31(9.0)$ & Unchanged & Unchanged \\
\hline \multicolumn{5}{|l|}{ Age $-y r$} \\
\hline Median & 39 & 46 & 43 & 49 \\
\hline Interquartile range & $34-45$ & $39-54$ & $38-49$ & $42-57$ \\
\hline Race or ethnic group — no./total no. (\%) $\dagger$ & & & Unchanged & Unchanged \\
\hline White & $11,130 / 14,291(77.9)$ & $210 / 234(89.7)$ & & \\
\hline Black & $2,413 / 14,291(16.9)$ & $21 / 234(9.0)$ & & \\
\hline Hispanic & $466 / 14,291(3.3)$ & $2 / 234(0.9)$ & & \\
\hline Asian & 273/14,291 (1.9) & $1 / 234(0.4)$ & & \\
\hline Other & $9 / 14,291(0.1)$ & $0 / 234$ & & \\
\hline \multicolumn{5}{|l|}{ Body-mass indext } \\
\hline$>30-$ no./total no. (\%) & $934 / 19,857$ (4.7) & $20 / 293(6.8)$ & $1,114 / 21,342(5.2)$ & $21 / 305(6.8)$ \\
\hline Median & 23.0 & 23.1 & 22.9 & 23.1 \\
\hline Interquartile range & $21.0-25.2$ & $21.3-25.6$ & $20.9-25.3$ & $20.8-25.7$ \\
\hline \multicolumn{5}{|l|}{ Cardiovascular risk factors } \\
\hline Current or former smoker — no./total no. (\%) & $10,893 / 17,911(60.8)$ & $196 / 264(74.2)$ & $14,053 / 19,558(71.9)$ & $225 / 279(80.6)$ \\
\hline Family history of coronary heart disease — no./total no. (\%)』 & $1,415 / 17,035(8.3)$ & $32 / 237(13.5)$ & $1,899 / 17,440(10.9)$ & $38 / 229(16.6)$ \\
\hline Previous cardiovascular disease - no. (\%) & $387(1.7)$ & $56(16.2)$ & $910(3.9)$ & $64(18.6)$ \\
\hline Hypertension — no. (\%)\| & $3,381(14.4)$ & $101(29.3)$ & $5,575(23.8)$ & $131(38.0)$ \\
\hline \multicolumn{5}{|l|}{ Systolic blood pressure $-\mathrm{mm} \mathrm{Hg}$} \\
\hline Median & 120 & 126 & 120 & 130 \\
\hline Interquartile range & $110-130$ & $120-140$ & $113-130$ & $120-140$ \\
\hline \multicolumn{5}{|l|}{ Diastolic blood pressure $-\mathrm{mm} \mathrm{Hg}$} \\
\hline Median & 80 & 80 & 80 & 80 \\
\hline Interquartile range & $70-80$ & $72-85$ & $70-83$ & $70-85$ \\
\hline Diabetes mellitus — no. (\%) ${ }^{*} *$ & $735(3.1)$ & $49(14.2)$ & $1,271(5.4)$ & $57(16.5)$ \\
\hline Dyslipidemia — no. (\%) †† & $9,833(42.0)$ & $224(64.9)$ & $11,389(48.6)$ & $238(69.0)$ \\
\hline \multicolumn{5}{|l|}{ Serum total cholesterol $-\mathrm{mmol} /$ literts } \\
\hline Median & 5.0 & 5.9 & 5.0 & 5.8 \\
\hline Interquartile range & $4.2-6.0$ & $5.0-7.0$ & $4.2-5.8$ & $4.9-6.7$ \\
\hline \multicolumn{5}{|l|}{ Serum HDL cholesterol - $\mathrm{mmol} /$ literț } \\
\hline Median & 1.1 & 1.0 & 1.1 & 1.1 \\
\hline Interquartile range & $0.9-1.4$ & $0.8-1.2$ & $0.9-1.4$ & $0.9-1.3$ \\
\hline \multicolumn{5}{|l|}{ Serum triglycerides - mmol/liter $\int \mathbb{~}$} \\
\hline Median & 1.7 & 2.5 & 1.7 & 2.4 \\
\hline Interquartile range & $1.1-2.8$ & $1.6-3.9$ & $1.1-2.7$ & $1.6-3.9$ \\
\hline \multicolumn{5}{|l|}{ Ratio of total to HDL cholesterol } \\
\hline Median & 4.4 & 5.6 & 4.3 & 5.7 \\
\hline Interquartile range & $3.4-5.6$ & $4.5-6.6$ & $3.4-5.5$ & $4.4-6.9$ \\
\hline Use of lipid-lowering agents — no. (\%) & $944(4.0)$ & $46(13.3)$ & $2,367(10.1)$ & $79(22.9)$ \\
\hline
\end{tabular}




\begin{tabular}{|c|c|c|c|c|}
\hline \multirow[t]{2}{*}{ Characteristic } & \multicolumn{2}{|c|}{ Baseline } & \multicolumn{2}{|c|}{ Last Follow-up } \\
\hline & $\begin{array}{l}\text { All Patients } \\
(\mathrm{N}=23,437)\end{array}$ & $\begin{array}{l}\text { Patients Who Had } \\
\text { a Myocardial } \\
\text { Infarction during } \\
\text { the Study } \\
(\mathrm{N}=345)\end{array}$ & $\begin{array}{l}\text { All Patients } \\
(\mathrm{N}=23,437)\end{array}$ & $\begin{array}{l}\text { Patients Who Had } \\
\text { a Myocardial } \\
\text { Infarction during } \\
\text { the Study } \\
(\mathrm{N}=345)\end{array}$ \\
\hline \multicolumn{5}{|l|}{ HIV disease characteristics } \\
\hline Clinical diagnosis of AIDS — no. (\%) & $6,191(26.4)$ & 117 (33.9) & $7,170(30.6)$ & $127(36.8)$ \\
\hline \multicolumn{5}{|l|}{ HIV-I RNA - $\log _{10}$ copies/ml } \\
\hline Median & 2.6 & 2.4 & 1.7 & 1.9 \\
\hline Interquartile range & $1.7-4.0$ & $1.7-3.8$ & $1.7-3.5$ & $1.7-3.3$ \\
\hline \multicolumn{5}{|l|}{ CD4+ lymphocyte count - cells $/ \mathrm{mm}^{3}$} \\
\hline Median & 420 & 368 & 461 & 411 \\
\hline Interquartile range & $258-617$ & $222-569$ & $297-661$ & $270-618$ \\
\hline \multicolumn{5}{|l|}{ 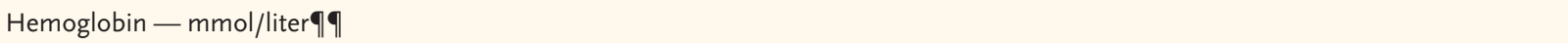 } \\
\hline Median & 8.8 & 8.9 & 8.8 & 8.9 \\
\hline Interquartile range & $8.1-9.4$ & $8.2-9.5$ & 8.0-9.4 & $8.1-9.4$ \\
\hline Lipodystrophy (including lipoatrophy) — no. (\%) & $5,135(21.9)$ & $107(31.0)$ & $7,844(33.5)$ & $131(38.0)$ \\
\hline \multicolumn{5}{|l|}{ Antiretroviral therapy } \\
\hline Not exposed to antiretroviral therapy — no. (\%) & $4,157(17.7)$ & $19(5.5)$ & $1,511(6.4)$ & $5(1.4)$ \\
\hline Exposed to antiretroviral therapy — no. (\%) & $19,267(82.2)$ & $326(94.5)$ & $21,926(93.6)$ & $340(98.6)$ \\
\hline \multicolumn{5}{|l|}{ Cumulative exposure for those exposed $-y r$} \\
\hline Median & 3.4 & 4.2 & 6.9 & 6.1 \\
\hline Interquartile range & $2.0-5.0$ & $2.7-5.8$ & $4.7-8.8$ & $4.2-8.2$ \\
\hline Exposed to protease inhibitors - no. (\%) & $16,096(68.7)$ & $292(84.6)$ & $18,607(79.4)$ & $312(90.4)$ \\
\hline \multicolumn{5}{|l|}{ Cumulative exposure for those exposed - yr } \\
\hline Median & 2.4 & 2.7 & 4.0 & 3.7 \\
\hline Interquartile range & $1.4-3.2$ & $1.9-3.4$ & $2.3-6.2$ & $2.4-5.1$ \\
\hline $\begin{array}{l}\text { Exposed to nonnucleoside reverse-transcriptase } \\
\text { inhibitors - no. (\%) }\end{array}$ & $8,163(34.8)$ & $149(43.2)$ & $14,932(63.7)$ & $210(60.9)$ \\
\hline \multicolumn{5}{|l|}{ Cumulative exposure for those exposed $-\mathrm{yr}$} \\
\hline Median & 0.9 & 1.1 & 2.6 & 2.1 \\
\hline Interquartile range & $0.4-1.5$ & $0.6-1.8$ & $1.2-4.4$ & $0.9-3.1$ \\
\hline
\end{tabular}

* Data for some characteristics were not available for all patients. HDL denotes high-density lipoprotein, AIDS the acquired immunodeficiency syndrome, and HIV human immunodeficiency virus.

$\dagger$ Race was self-assessed or ascertained by health care personnel, depending on the clinic. The percentages for the entire cohort do not sum to 100 because of rounding.

7 The body-mass index is the weight in kilograms divided by the square of the height in meters.

$\int$ A family history of coronary heart disease was defined as at least one first-degree relative who had had the disease before the age of 50 years.

I Previous cardiovascular events were defined as a history of myocardial infarction, stroke, or invasive procedures for stenosis of the carotid or coronary arteries.

|| Hypertension was defined as a systolic blood pressure of at least $140 \mathrm{~mm} \mathrm{Hg}$, a diastolic blood pressure of at least $90 \mathrm{~mm} \mathrm{Hg}$, or use of antihypertensive drugs.

$*$ Patients with diabetes were defined as those who had a diagnosis of diabetes or were taking antidiabetic drugs.

$\dagger †$ Dyslipidemia was defined as a total serum cholesterol level of at least $6.2 \mathrm{mmol}$ per liter (240 $\mathrm{mg}$ per deciliter), a total triglyceride level of at least $2.3 \mathrm{mmol}$ per liter (204 mg per deciliter), an HDL cholesterol level of $0.9 \mathrm{mmol}$ per liter ( $35 \mathrm{mg}$ per deciliter) or less, or use of lipid-lowering drugs.

To convert values for cholesterol to milligrams per deciliter, divide by 0.02586 .

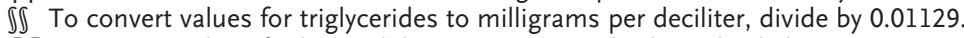

१ी To convert values for hemoglobin to grams per deciliter, divide by 0.6206 . 


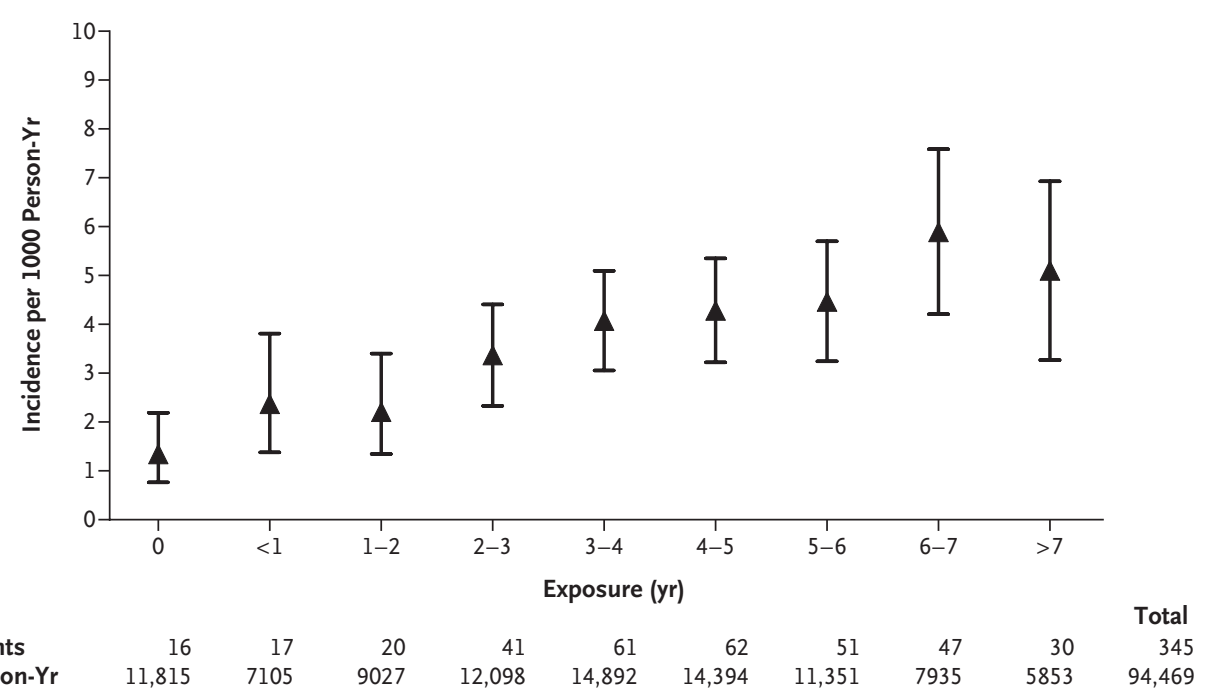

Figure 1. Risk of Myocardial Infarction According to Exposure to Combination Antiretroviral Therapy.

The crude incidence of primary events was assessed beginning at baseline according to the cumulative duration of combination antiretroviral therapy since the initiation of therapy, stratified in 1-year intervals from the initiation of therapy to more than 7 years of exposure. The adjusted relative rate of myocardial infarction according to cumulative exposure to combination antiretroviral therapy was 1.16 per year of exposure $(95 \% \mathrm{Cl}, 1.09$ to 1.23$)$. The estimate was based on a Poisson regression model. The multivariable model was adjusted for age, sex, family history of coronary heart disease, body-mass index, smoking status, history of cardiovascular disease, cohort, transmission group, race or ethnic group, and calendar year. The sum of the person-years does not total 94,469 because of rounding. The I bars denote the $95 \% \mathrm{Cls}$.

exposed to protease inhibitors to 6.01 per 1000 person-years among those exposed to protease inhibitors for more than 6 years. However, because many patients had been exposed to both drug classes, the unadjusted event rates are not independent. After adjustment for exposure to the other drug class, calendar year, and other known risk factors for myocardial infarction (excluding those that have been reported to have an association with antiretroviral-drug therapy), the relative rate per year of exposure to protease inhibitors was 1.16 (95\% CI, 1.10 to 1.23), whereas for nonnucleoside reverse-transcriptase inhibitors it was 1.05 (95\% CI, 0.98 to 1.13; Fig. 2B and Table 2, adjusted model 1 ). These associations were confirmed when patients exposed to the other drug class were excluded (Fig. 3). The adjusted relative rate per year of exposure to protease inhibitors for this subgroup of patients was 1.15 (95\% CI, 1.06 to 1.25). The adjusted relative rate per year of exposure to nonnucleoside reverse-transcriptase inhibitors was 0.94 ( $95 \% \mathrm{CI}, 0.74$ to 1.19 ).

The crude incidence rate of myocardial infarction was increased among patients who received drugs of both classes at the same time (97 events in 16,805 person-years; incidence, 5.77 per 1000 person-years) as compared with the entire cohort (incidence, 3.65 per 1000 person-years). However, this difference was explained by the longer exposure to protease inhibitors of patients receiving drugs of both classes (relative rate for exposure to both drug classes after adjustment for duration of exposure to each class, 1.03 per year).

Controlling for exposure to nucleoside reversetranscriptase inhibitors as a class reduced the strength of the associations for protease inhibitors (relative rate, $1.11 ; 95 \%$ CI, 1.04 to 1.18 ) and for nonnucleoside reverse-transcriptase inhibitors (relative rate, 1.02; 95\% CI, 0.95 to 1.10). There were no major differences between the two drug classes in exposure to individual components of the nucleoside reverse-transcriptase inhibitor backbone.

Increased total cholesterol and reduced HDL cholesterol levels, increased triglyceride levels, and a diagnosis of hypertension or diabetes are risk factors for coronary heart disease that have been reported to be associated with antiretroviral- 


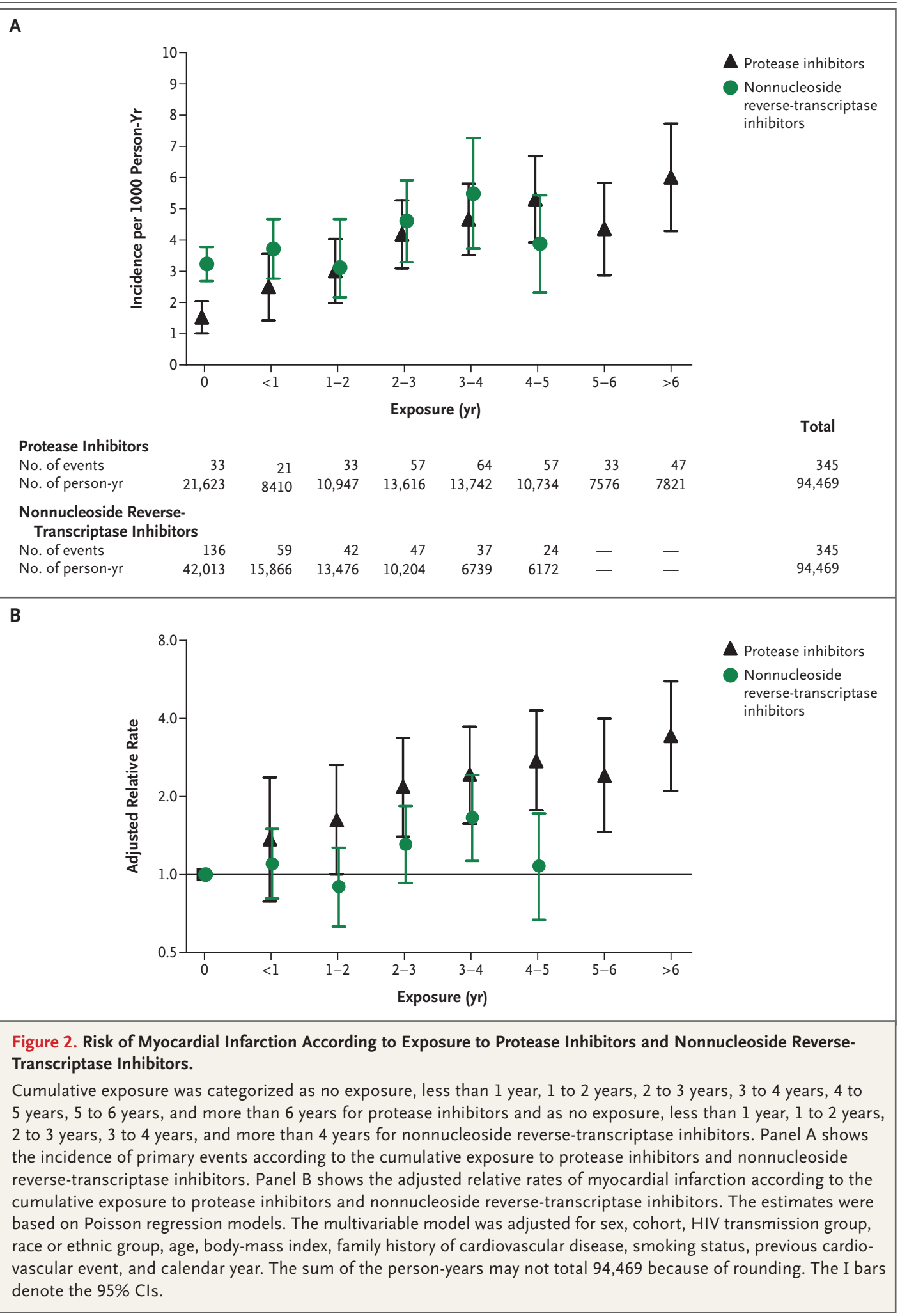

N ENGLJ MED 356;17 WWW.NEJM.ORG APRIL 26, 2007

The New England Journal of Medicine 


\begin{tabular}{|c|c|c|c|c|c|c|}
\hline \multirow[t]{2}{*}{ Variable } & \multicolumn{2}{|c|}{ Unadjusted Model } & \multicolumn{2}{|c|}{ 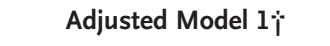 } & \multicolumn{2}{|c|}{ Adjusted Model $2 \%$} \\
\hline & $\begin{array}{l}\text { Relative Rate } \\
\quad(95 \% \mathrm{Cl})\end{array}$ & P Value & $\begin{array}{l}\text { Relative Rate } \\
\quad(95 \% \mathrm{CI})\end{array}$ & P Value & $\begin{array}{l}\text { Relative Rate } \\
\quad(95 \% \mathrm{CI})\end{array}$ & PValue \\
\hline $\begin{array}{l}\text { Exposure to protease inhibitors (per additional } \\
\text { year) }\end{array}$ & $1.17(1.12-1.23)$ & $<0.001$ & $1.16(1.10-1.23)$ & $<0.001$ & $1.10(1.04-1.18)$ & 0.002 \\
\hline $\begin{array}{l}\text { Exposure to nonnucleoside reverse-transcriptase } \\
\text { inhibitors (per additional year) }\end{array}$ & $1.07(1.00-1.14)$ & 0.04 & $1.05(0.98-1.13)$ & 0.17 & $1.00(0.93-1.09)$ & 0.92 \\
\hline Age (per additional $5 \mathrm{yr}$ ) & $1.41(1.35-1.48)$ & $<0.001$ & $1.39(1.31-1.46)$ & $<0.001$ & $1.32(1.23-1.41)$ & $<0.001$ \\
\hline Male sex & $3.27(2.26-4.73)$ & $<0.001$ & $1.91(1.28-2.86)$ & 0.002 & $2.13(1.29-3.52)$ & 0.003 \\
\hline \multicolumn{7}{|l|}{ Body-mass index $\mathbb{\int}$} \\
\hline$<18$ & $0.74(0.37-1.50)$ & 0.41 & $0.74(0.36-1.50)$ & 0.40 & $0.92(0.43-1.97)$ & 0.84 \\
\hline $18-269$ & 1 & & 1 & & 1 & \\
\hline$>26-30$ & $1.12(0.82-1.53)$ & 0.47 & $1.06(0.78-1.45)$ & 0.70 & $0.88(0.61-1.27)$ & 0.48 \\
\hline$>30$ & $1.41(0.90-2.20)$ & 0.13 & $1.70(1.08-2.69)$ & 0.02 & $1.34(0.77-2.34)$ & 0.31 \\
\hline Not known & $1.14(0.81-1.59)$ & 0.46 & $1.19(0.84-1.71)$ & 0.33 & $1.34(0.86-2.09)$ & 0.19 \\
\hline \multicolumn{7}{|l|}{ Family history of coronary heart disease $\|$} \\
\hline Nol & 1 & & 1 & & 1 & \\
\hline Yes & $1.83(1.29-2.59)$ & $<0.001$ & $1.56(1.10-2.23)$ & 0.01 & $1.40(0.96-2.05)$ & 0.08 \\
\hline Not known & $1.48(1.17-1.86)$ & $<0.001$ & $1.64(1.20-2.24)$ & 0.002 & $1.32(0.92-1.91)$ & 0.13 \\
\hline \multicolumn{7}{|l|}{ Smoking status } \\
\hline Current & $2.17(1.59-2.94)$ & $<0.001$ & $2.83(2.04-3.93)$ & $<0.001$ & $2.92(2.04-4.18)$ & $<0.001$ \\
\hline Former & $1.96(1.35-2.86)$ & $<0.001$ & $1.65(1.12-2.42)$ & 0.01 & $1.63(1.07-2.48)$ & 0.02 \\
\hline Never $\emptyset$ & 1 & & 1 & & 1 & \\
\hline Not known & $1.83(1.28-2.63)$ & 0.001 & $1.70(1.07-2.71)$ & 0.03 & $1.67(0.96-2.92)$ & 0.07 \\
\hline \multicolumn{7}{|l|}{ Previous cardiovascular event } \\
\hline Nol & 1 & & 1 & & 1 & \\
\hline Yes & $9.72(7.06-13.38)$ & $<0.001$ & $4.30(3.06-6.03)$ & $<0.001$ & $4.64(3.22-6.69)$ & $<0.001$ \\
\hline Diabetes mellitus $* *$ & $4.05(3.05-5.38)$ & $<0.001$ & - & - & $1.86(1.31-2.65)$ & $<0.001$ \\
\hline Hypertensiont广 & $2.53(1.99-3.21)$ & $<0.001$ & - & - & $1.30(0.99-1.72)$ & 0.06 \\
\hline Total cholesterol (per mmol/liter increase) & $1.31(1.25-1.37)$ & $<0.001$ & - & - & $1.26(1.19-1.35)$ & $<0.001$ \\
\hline HDL cholesterol (per mmol/liter increase) & $0.65(0.48-0.88)$ & $<0.001$ & - & - & $0.72(0.52-0.99)$ & 0.05 \\
\hline Triglycerides (per doubling of the concentration) & $1.58(1.43-1.75)$ & $<0.001$ & - & - & - & - \\
\hline
\end{tabular}

* All 23,437 patients were included in the models shown. $\mathrm{Cl}$ denotes confidence interval, dashes not applicable, and HDL high-density lipoprotein.

$\dagger$ The primary model (model 1 ) was adjusted for sex, cohort, HIV transmission group, race or ethnic group (all fixed at enrollment in DAD), age, body-mass index, family history of cardiovascular disease, smoking status, previous cardiovascular event, and calendar year (all timeupdated to allow a patient's status to change over time).

$\mp$ In an additional exploratory model (model 2), we assessed the role of established risk factors for myocardial infarction that may potentially be influenced by antiretroviral therapy, including the levels of serum lipids (total cholesterol and HDL cholesterol), hypertension, and the presence of diabetes mellitus. For each variable, the patient's most recent measurement at the start of each month was incorporated into the model in a time-updated manner (this analysis excluded patients with missing information on covariates). Thus, the latter analysis allowed us to assess potential mechanisms for any apparent relationship between myocardial infarction and exposure to therapy. The model was also adjusted for the same factors as model 1.

$\int$ The body-mass index is the weight in kilograms divided by the square of the height in meters.

I The patients in this category served as the reference group.

|| A family history of coronary heart disease was defined as at least one first-degree relative who had had the disease before the age of 50 years.

** Patients with diabetes were defined as those who had a diagnosis of diabetes or were taking antidiabetic drugs.

$\dagger \dagger$ Hypertension was defined as a systolic blood pressure of at least $140 \mathrm{~mm} \mathrm{Hg}$, a diastolic blood pressure of at least $90 \mathrm{~mm} \mathrm{Hg}$, or use of antihypertensive drugs.

+ Because of the strong associations among the three lipid measurements, triglycerides were not included in the multivariable model. 


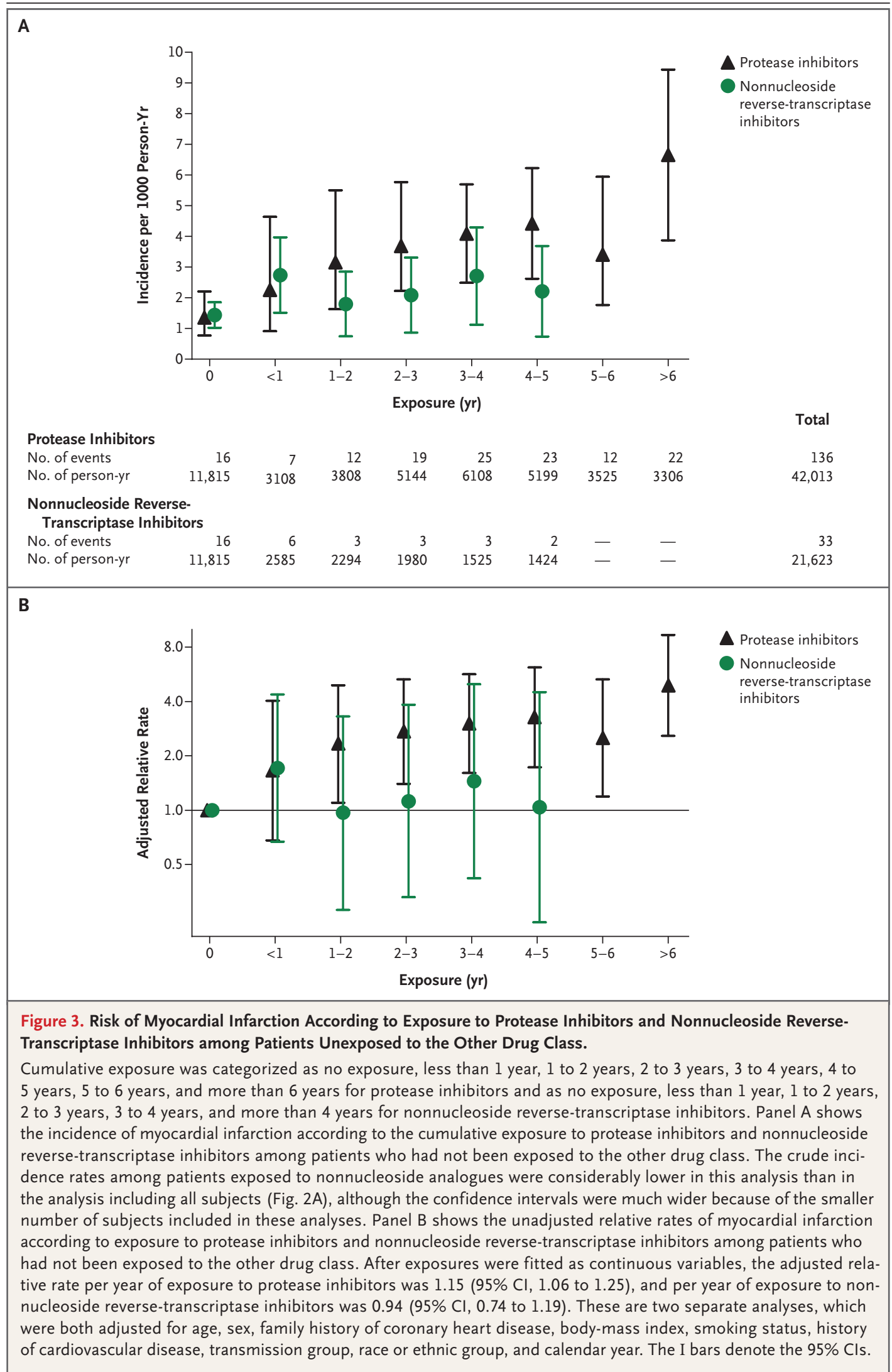

N ENGLJ MED 356;17 WWW.NEJM.ORG APRIL 26, 2007

The New England Journal of Medicine 
drug therapy. We confirmed that in our cohort, these factors were all associated with an increased risk of myocardial infarction in unadjusted analyses (Table 2, unadjusted model). Introducing these factors into adjusted model 1 in Table 2 as time-updated covariates decreased the association between exposure to protease inhibitors and the risk of myocardial infarction (Table 2, adjusted model 2). A model that included the lipids only (without diabetes mellitus and hypertension) reduced the association with protease inhibitors to a value similar to that in adjusted model 2 .

There was no association between either the nadir CD4+ lymphocyte count (relative rate for each increase of 50 cells per cubic millimeter, 0.98 ; $95 \%$ CI, 0.95 to 1.01 ) or peak HIV-1 RNA level (relative rate for each $\log _{10}$ increase in the number of copies per milliliter, 1.06; 95\% CI, 0.95 to 1.18 ) and the risk of myocardial infarction. Adjustment for these variables did not modify the association between exposure to protease inhibitors and the risk of myocardial infarction.

\section{DISCUSSION}

Using a data set that has accrued almost three times more end points in the 3 years of follow-up since the last report, ${ }^{5}$ we continue to observe an association between exposure to combination antiretroviral therapy and the risk of myocardial infarction. The relationship between exposure to protease inhibitors and myocardial infarction remained significant after multivariable adjustment and was similar to the relationship between exposure to any combination antiretroviral therapy and the risk of myocardial infarction. In contrast, exposure to nonnucleoside reverse-transcriptase inhibitors was not independently associated with an increase in the risk of myocardial infarction. Although experience with nonnucleoside reversetranscriptase inhibitors remains relatively limited, our results suggest that the previously reported finding of an excess risk in those with increased exposure to combination antiretroviral therapy is likely to be a consequence of exposure to the drugs of the protease-inhibitor class.

Protease inhibitors are known to increase total cholesterol and low-density lipoprotein cholesterol levels to a greater extent than do nonnucleoside reverse-transcriptase inhibitors, whereas the latter class of agents is known to increase HDL cholesterol levels markedly. ${ }^{15-17}$ However, the increased risk of myocardial infarction associated with the use of protease inhibitors seen in our analysis was not fully explained by the lipid changes induced by the drugs in this class. Thus, the full mechanism by which protease inhibitors may lead to increased rates of myocardial infarction remains to be elucidated. Recently published experimental data from murine models suggest possible direct cellular mechanisms by which HIV protease inhibitors may promote atherosclerosis. ${ }^{18,19}$ Furthermore, there are considerable differences among the various protease inhibitors in their propensity to cause dyslipidemia. ${ }^{16,20}$ The DAD study currently has insufficient follow-up observations to determine whether the risk of myocardial infarction differs for individual agents.

Some studies have reported that among patients receiving antiretroviral therapy, the degree of dyslipidemia or the risk of coronary heart disease is higher in women ${ }^{21,22}$ or in younger patients. ${ }^{23}$ In our analysis, we did not find any evidence that the therapy-attributable risk differs according to age or sex.

In our study, the relative rate of myocardial infarction was 1.16 per year of combination antiretroviral therapy, which corresponds to a doubling of the risk over a 5-year period of exposure. The magnitude of this association is similar to the increment in risk attributable to diabetes mellitus or cigarette smoking and is greater than that associated with a family history of cardiovascular disease. Whether this effect translates into an important additional absolute risk in a person depends on his or her preexisting cardiovascular-disease risk profile. In this regard, our analysis confirmed that the expected associations of established cardiovascular risk factors with myocardial infarction are also seen in the patient population of the DAD study, but our models were not intended to provide the formal basis for calculating individual cardiovascular risk.

We found no association between either the peak HIV-1 RNA level or the nadir CD4+ lymphocyte count and the risk of myocardial infarction, although the possibility that other unmeasured immunologic effects may exert an influence on the development of cardiovascular disease cannot be excluded. The Strategies for Management of Antiretroviral Therapy (SMART) study found that the risk of opportunistic disease or death from any cause was higher in patients whose antiretroviral therapy was interrupted when their 
CD4+ lymphocyte count reached a certain level than in patients who received continuous treatment. ${ }^{24}$ Surprisingly, the interruption strategy was also associated with a trend toward an excess risk of cardiovascular disease. The reasons for this finding remain unclear. Theoretically, it could be due to arterial inflammation, a reduction in HDL cholesterol levels, or both caused by an acuteonset increase in viral replication upon interruption of antiretroviral treatment. ${ }^{25-28}$ The latter effect may be particularly important after discontinuation of nonnucleoside reverse-transcriptase inhibitors, since these may in themselves cause a rise in HDL cholesterol level. ${ }^{15-17}$

Only a randomized trial, which is not feasible in this setting, could determine whether the observed associations of exposure to protease inhibitors and nonnucleoside reverse-transcriptase inhibitors with the risk of myocardial infarction are causally related. The DAD study, which is observational in design, relies on adjustment of the analyses of association for variables that could potentially act as confounders for these associations. In our analysis, we made adjustments for patient demographics and for the established cardiovascular risk factors. We also adjusted for calendar year to account for secular changes in the management of cardiovascular disease and in the use of antiretroviral agents.

However, there are likely to be other confounding factors that are unknown or are not routinely or easily identified or measured. One possible interpretation of the significant relationship between the risk of myocardial infarction and the length of exposure to combination antiretroviral therapy may be simply that patients with longer periods of exposure to therapy have also been infected with HIV for longer periods. However, our findings that neither the nadir CD4+ count nor the peak HIV-1 RNA level was associated with the risk of myocardial infarction would argue against this interpretation, as would the finding that the risk is different for exposure to nonnucleoside reverse-transcriptase inhibitors and exposure to protease inhibitors.

Another possible concern in observational studies of this type is channeling bias. In our study, channeling bias could have occurred if patients perceived to be at highest risk for cardiovascular disease were either started on or switched to regimens thought to be cardioprotective. Such a bias would tend to reduce the strength of the associa- tion of protease-inhibitor exposure with the risk of myocardial infarction. The fact that our analyses are adjusted for most known risk factors for cardiovascular disease reduces the likelihood that channeling has unduly influenced our results. In addition, we assessed the relationship of myocardial infarction with cumulative exposure to an antiretroviral drug rather than with current treatment with an antiretroviral drug, which further reduces the chance of significant bias. Finally, other analyses from the DAD study ${ }^{29}$ suggest that changes in therapy made because of concern about cardiovascular disease are unlikely to have been frequent enough to bias our results.

In conclusion, this analysis confirmed our previous observation of a significant association between the duration of exposure to combination antiretroviral therapy and the risk of myocardial infarction. In addition, our findings suggest that this effect of antiretroviral therapy varies according to drug class; we found a significant association between exposure to protease inhibitors and the risk of myocardial infarction but no significant association between nonnucleoside reverse-transcriptase inhibitors and such a risk. The effect of protease inhibitors identified in our study may be in part a consequence of the effects of these agents on serum lipid profiles.

Supported by the Oversight Committee for the Evaluation of Metabolic Complications of HAART, a collaborative committee with representation from academic institutions, the European Agency for the Evaluation of Medicinal Products, the Food and Drug Administration, the patient community, and all pharmaceutical companies with licensed anti-HIV drugs in the U.S. market: Abbott, Boehringer Ingelheim, Bristol-Myers Squibb, Gilead Sciences, GlaxoSmithKline, Merck, Pfizer, and Hoffmann-La Roche; by a grant (CURE/97-46486) from the Health Insurance Fund Council, Amstelveen, the Netherlands (to the AIDS Therapy Evaluation Project Netherlands [ATHENA]); by a grant from the Agence Nationale de Recherches sur le SIDA (Action Coordonnée no. 7, Cohortes) (to the Aquitaine Cohort); by the Commonwealth Department of Health and Ageing and a grant from the Australian National Council on AIDS, Hepatitis C and Related Diseases' Clinical Trials and Research Committee (to the Australian HIV Observational Database [AHOD]); by grants from the Fondo de Investigación Sanitaria (FIS 99/0887) and the Fundación para la Investigación y la Prevención del SIDA en España (FIPSE 3171/00) (to the Barcelona Antiretroviral Surveillance Study [BASS]); by grants (5U01AI042170-10 and 5U01AI046362-03) from the National Institute of Allergy and Infectious Diseases, National Institutes of Health (to the Terry Beirn Community Programs for Clinical Research on AIDS [CPCRA]); by grants from the BIOMED 1 (CT94-1637) and BIOMED 2 (CT97-2713) programs and the fifth framework program (QLK2-2000-00773) of the European Commission and grants from Bristol-Myers Squibb, GlaxoSmithKline, Boehringer Ingelheim, and Roche (to the EuroSIDA study); by an unrestricted educational grant from Glaxo Wellcome, Italy (to the Italian Cohort Naive to Antiretrovirals [ICONA]); and by a grant from the Swiss National Science Foundation (to the Swiss HIV Cohort Study [SHCS]). 
Dr. Friis-Mфller reports receiving lecture fees from BristolMyers Squibb; Dr. Reiss, serving as a consultant to and receiving lecture fees from Boehringer Ingelheim, Bristol-Myers Squibb, Gilead Sciences, GlaxoSmithKline, Hoffmann-La Roche, Theratechnologies, and Tibotec and receiving research grant support from Boehringer Ingelheim and Merck; Dr. Sabin, serving as a consultant to Gilead Sciences and Tibotec and receiving lecture fees from Bristol-Myers Squibb, Gilead Sciences, and Tibotec; Dr. Weber, receiving travel grants from Abbott, Boehringer Ingelheim, Bristol-Myers Squibb, GlaxoSmithKline, Merck, Pfizer, Hoffmann-La Roche, and TRB Chemedica; Dr. d'Arminio Mon- forte, serving as a consultant and receiving lecture fees and research support from GlaxoSmithKline; Dr. Law, serving as a consultant to Johnson \& Johnson and Janssen-Cilag; Dr. Phillips, serving as a consultant to Tibotec and Boehringer Ingelheim and receiving research grant support from GlaxoSmithKline, Bristol-Myers Squibb, Abbott, Janssen-Cilag, and Tibotec; and Dr. Lundgren, serving as a consultant to and receiving lecture fees and research grant support from Abbott, Boehringer Ingelheim, Bristol-Myers Squibb, GlaxoSmithKline, Merck, Pfizer, Tibotec, and Hoffmann-La Roche. No other potential conflict of interest relevant to this article was reported.

\section{APPENDIX}

The members of the DAD Study Group are as follows: Steering committee: J.D. Lundgren (chair), R. Weber, A. d'Arminio Monforte, W.M. El-Sadr, P. Reiss, F. Dabis, L. Morfeldt, S. De Wit, C. Pradier, G. Calvo, M. Law, O. Kirk, A.N. Phillips, S. Collins, E. Loeliger, R. Tressler, and I. Weller; Central coordination: N. Friis-Mфller, S.W. Worm, C.A. Sabin, A. Sjфl (verification of primary end point), J.D. Lundgren; Data management: A. Sawitz (coordinator), M. Rickenbach, P. Pezzotti, E. Krum, L. Gras, E. Balestre, A. Sundström, B. Poll, E. Fontas, F. Torres, K. Petoumenos, J. Kjær.

The members of the 11 cohorts are as follows: ATHENA (AIDS Therapy Evaluation Project, the Netherlands): Central coordination: F. de Wolf, S. Zaheri, L. Gras; Participating physicians: W. Bronsveld, M.E. Hillebrand-Haverkort, J.M. Prins, J.C. Bos, J.K.M. Eeftinck Schattenkerk, S.E. Geerlings, M.H. Godfried, J.M.A. Lange, F.C. van Leth, S.H. Lowe, J.T.M. van der Meer, F.J.B. Nellen, K. Pogány, T. van der Poll, P. Reiss, T.A. Ruys, S.U. Sankatsing, R. Steingrover, G. van Twillert, M. van der Valk, M.G.A. van Vonderen, S.M.E. Vrouenraets, M. van Vugt, F.W.M.N. Wit, A. van Eeden, J.H. ten Veen, P.S. van Dam, J.C. Roos, K. Brinkman, P.H.J. Frissen, H.M. Weigel, J.W. Mulder, E.C.M. van Gorp, P.L. Meenhorst, A.T.A. Mairuhu, J. Veenstra, S.A. Danner, M.A. Van Agtmael, F.A.P. Claessen, R.M. Perenboom, A. Rijkeboer, M. van Vonderen, C. Richter, J. van der Berg, R. van Leusen, R. Vriesendorp, F.J.F. Jeurissen, R.H. Kauffmann, E.L.W. Koger, B. Bravenboer, C.H.H. ten Napel, G.J. Kootstra, H.G. Sprenger, W.M.A.J. Miesen, R. Doedens, E.H. Scholvinck, R.W. ten Kate, D.P.F. van Houte, M. Polee, F.P. Kroon, P.J. van den Broek, J.T. van Dissel, E.F. Schippers, G. Schreij, S. van de Geest, A. Verbon, P.P. Koopmans, M. Keuter, F. Post, A.J.A.M. van der Ven, M.E. van der Ende, I.C. Gyssens, M. van der Feltz, J.G. den Hollander, S. de Marie, J.L. Nouwen, B.J.A. Rijnders, T.E.M.S. de Vries, J.R. Juttmann, C. van de Heul, M.E.E. van Kasteren, M.M.E. Schneider, M.J.M. Bonten, J.C.C. Borleffs, P.M. Ellerbroek, I.M. Hoepelman, C.A.J.J. Jaspers, I. Schouten, C.A.M. Schurink, W.L. Blok, A.A. Tanis, P.H.P. Groeneveld. Aquitaine (France): Scientific committee: R. Salamon (chair), J. Beylot, M. Dupon, M. Le Bras, J.L. Pellegrin, J.M. Ragnaud; Central coordination: F. Dabis, G. Chêne, H. Jacqmin-Gadda, R. Thiébaut, S. Lawson-Ayayi, V. Lavignolle, E. Balestre, M.J. Blaizeau, M. Decoin, A.M. Formaggio, S. Delveaux, S. Labarerre, B. Uwamaliya, E. Vimard, L. Merchadou, G. Palmer, D. Touchard, D. Dutoit, F. Pereira, B. Boulant; Participating physicians: J. Beylot, P. Morlat, N. Bernard, M. Bonarek, F. Bonnet, B. Coadou, P. Gelie, D. Jaubert, C. Nouts, D. Lacoste, M. Dupon, H. Dutronc, G. Cipriano, S. Lafarie, I. Chossat, J.Y. Lacut, B. Leng, J.L. Pellegrin, P. Mercié, J.F. Viallard, I. Faure, P. Rispal, C. Cipriano, S. Tchamgoué, M. Le Bras, F. Djossou, D. Malvy, J.P. Pivetaud, J.M. Ragnaud, D. Chambon, C. De La Taille, T. Galperine, S. Lafarie, D. Neau, A. Ochoa, C. Beylot, M.S. Doutre, J.H. Bezian, J.F. Moreau, J.L. Taupin, C. Conri, J. Constans, P. Couzigou, L. Castera, H. Fleury, M.E. Lafon, B. Masquelier, I. Pellegrin, P. Trimoulet, F. Moreau, C. Mestre, C. Series, A. Taytard. AHOD (Australian HIV Observational Database, Australia): Central coordination: M. Law and K. Petoumenos; Participating physicians: J. Anderson, K. Lowe, A. Mijch, K. Watson, N. Roth, H. Wood, M. Bloch, A. Gowers, D. Baker, R. McFarlane, A. Carr, D. Cooper, J. Chuah, W. Fankhauser, S. Mallal, J. Skett. BASS (Barcelona Antiretroviral Surveillance Study, Spain): Central coordination: G. Calvo, F. Torres, S. Mateu; Participating physicians: P. Domingo, M.A. Sambeat, J. Gatell, E. Del Cacho, J. Cadafalch, M. Fuster, C. Codina, G. Sirera, A. Vaqué. The Brussels St. Pierre Cohort (Belgium): N. Clumeck, S. De Wit, M. Gerard, K. Kabeya, D. Konopnicki, A. Libois, M.C. Payen, B. Poll, Y. Van Laethem. CPCRA (Community Programs for Clinical Research on AIDS, United States): Central coordination: J. Neaton, G. Bartsch, W.M. El-Sadr, E. Krum, G. Thompson, D. Wentworth; Participating physicians: R. Luskin-Hawk, E. Telzak, W.M. El-Sadr, D.I. Abrams, D. Cohn, N. Markowitz, R. Arduino, D. Mushatt, G. Friedland, G. Perez, E. Tedaldi, E. Fisher, F. Gordin, L.R. Crane, J. Sampson, J. Baxter. EuroSIDA (multinational): Central coordination: O. Kirk, C.H. Olsen, A. Mocroft, A.N. Phillips, J.D. Lundgren; Participating physicians: Austria - N. Vetter; Belarus - I. Karpov, A. Vassilenko; Belgium - N. Clumeck, S. De Wit, B. Poll, R. Colebunders; Czech Republic - L. Machala, H. Rozsypal, D. Sedlacek; Denmark - J. Nielsen, T. Benfield, J. Gerstoft, T. Katzenstein, A.B.E. Hansen, P. Skinh $\phi$ j, C. Pedersen; Estonia - K. Zilmer; France - C. Katlama, J.-P. Viard, P.-M. Girard, T. Saint-Marc, P. Vanhems, C. Pradier, F. Dabis; Germany - M. Dietrich, C. Manegold, J. van Lunzen, H.-J. Stellbrink, S. Staszewski, M. Bieckel, F.D. Goebel, G. Fätkenheuer, J. Rockstroh, R.E. Schmidt; Greece - J. Kosmidis, P. Gargalianos, H. Sambatakou, J. Perdios, G. Panos, A. Filandras; Hungary - D. Banhegyi; Ireland - F. Mulcahy; Israel - I. Yust, M. Burke, D. Turner, S. Pollack, J. Hassoun, Z. Sthoeger, S. Maayan; Italy — S. Vella, A. Chiesi, C. Arici, R. Pristerá, F. Mazzotta, A. Gabbuti, R. Esposito, A. Bedini, A. Chirianni, E. Montesarchio, V. Vullo, P. Santopadre, P. Narciso, A. Antinori, P. Franci, M. Zaccarelli, A. Lazzarin, A. Castagna, A. d'Arminio Monforte; Latvia — L. Viksna; Lithuania - S. Chaplinskas; Luxembourg - R. Hemmer, T. Staub; the Netherlands - P. Reiss; Norway - J. Bruun, A. Maeland, V. Ormaasen; Poland - B. Knysz, J. Gasiorowski, A. Horban, D. Prokopowicz, A. Wiercinska-Drapalo, A. Boron-Kaczmarska, M. Pynka, M. Beniowski, E. Mularska, H. Trocha; Portugal - F. Antunes, K. Mansinho, F. Maltez; Romania - D. Duiculescu, V. Babes, A. Streinu-Cercel; Russia - E. Vinogradova, A. Rakhmanova; Serbia, Montenegro - D. Jevtovic; Slovakia - M. Mokrášs, D. Staneková; Spain - J. González-Lahoz, M. Sanchez-Conde, T. García-Benayas, L. Martin-Carbonero, V. Soriano, B. Clotet, A. Jou, J. Conejero, L. Ruiz, C. Tural, J.M. Gatell, J.M. Miró, L. Zamora; Sweden - A. Blaxhult, A. Karlsson, P. Pehrson; Switzerland - B. Ledergerber, R. Weber, P. Francioli, A. Telenti, B. Hirschel, V. Soravia-Dunand, H. Furrer; Ukraine - E. Kravchenko, N. Chentsova; United Kingdom - M. Fisher, R. Brettle, S. Barton, A.M. Johnson, D. Mercey, M. Murphy, M.A. Johnson, J. Weber, G. Scullard. HivBivus (Sweden): Central coordination: L. Morfeldt, G. Thulin, A. Sundström; Participating physicians: B. Åkerlund, K. Koppel, A. Karlsson, L. Flamholc, C. Håkangård. ICONA (Italian Cohort Naive to Antiretrovirals, Italy): Central coordination: A. d'Arminio Monforte, P. Pezzotti; Participating physicians: M. Moroni, A. d'Arminio Monforte, A. Cargnel, S. Merli, G. Rizzardini, C. Pastecchia, A. Lazzarin, A. Castagna, L. Caggese, C. Moioli, M.S. Mura, M. Mannazzu, F. Suter, C. Arici, P.E. Manconi, P. Piano, F. Mazzotta, S. Lo Caputo, A. Poggio, G. Bottari, G. Pagano, A. Alessandrini, A. Scasso, A. Vincenti, V. Abbadessa, S. Mancuso, F. Alberici, A. Ruggieri, M. Arlotti, P. Ortolani, F. De Lalla, 
G. Tositti, G. Cassola, R. Piscopo, E. Raise, F. Ebo, F. Soscia, L. Tacconi, U. Tirelli, G. Di Gennaro, D. Santoro, L. Pusterla, G. Carosi, C. Torti, G. Cadeo, D. Bertelli, G. Carnevale, D. Galloni, G. Filice, R. Bruno, G. Di Perri, I. Arnaudo, P. Caramello, G.C. Orofino, M.L. Soranzo, M. Bonasso, T. Quirino, S. Melzi, F. Chiodo, V. Colangeli, G. Magnani, M. Ursitti, F. Menichetti, C. Martinelli, R. Esposito, C. Mussini, F. Ghinelli, L. Sighinolfi, O. Coronado, G. Ballardini, E. Rizzo, M. Montroni, M.C. Braschi, E. Petrelli, A. Cioppi, R. Cauda, A. De Luca, N. Petrosillo, P. Noto, P. Narciso, G. Bontempo, A. Antinori, R. Acinapura, G. Antonucci, P. De Longis, V. Vullo, M. Lichtner, G. Pastore, N. Ladisa, A. Chirianni, R. Viglietti, M. Piazza, S. Nappa, N. Abrescia, M. De Marco, A. Colomba, T. Prestileo, C. De Stefano, A. La Gala, L. Cosco, A. Scerbo, P. Grima, P. Tundo, J. Vecchiet, M. D'Alessandro, B. Grisorio, S. Ferrara. The Nice Cohort (France): Central coordination: C. Pradier, E. Fontas, C. Caissotti; Participating physicians: P. Dellamonica, L. Bentz, E. Bernard, F. De Salvador-Guillouet, J. Durant, V. Mondain-Miton, I. Perbost, B. Prouvost-Keller, P. Pugliese, V. Rahelinirina, P.M. Roger, F. Vandenbos. SHCS (Swiss HIV Cohort Study, Switzerland): M. Battegay, E. Bernasconi, J. Böni, H. Bucher, P. Bürgisser, S. Cattacin, M. Cavassini, R. Dubs, M. Egger, L. Elzi, P. Erb, M. Fischer, M. Flepp, A. Fontana, P. Francioli (President), H.J. Furrer, M. Gorgievski, H. Günthard, B. Hirschel, L. Kaiser, C. Kind, T. Klimkait, U. Lauper, B. Ledergerber, M. Opravil, F. Paccaud, G. Pantaleo, L. Perrin, J.-C. Piffaretti, M. Rickenbach, C. Rudin, P. Schmid, J. Schüpbach, R. Speck, A. Telenti, A. Trkola, P. Vernazza, R. Weber, S. Yerly.

\section{REFERENCES}

1. Palella FJ Jr, Delaney KM, Moorman AC, et al. Declining morbidity and mortality among patients with advanced human immunodeficiency virus infection. $\mathrm{N}$ Engl J Med 1998;338:853-60.

2. Ledergerber B, Egger M, Opravil M, et al. Clinical progression and virologica failure on highly active antiretroviral therapy in HIV-1 patients: a prospective cohort study. Lancet 1999;353:863-8.

3. Mocroft A, Vella S, Benfield TL, et al. Changing patterns of mortality across Europe in patients infected with HIV-1. Lancet 1998;352:1725-30.

4. Staszewski S, Morales-Ramirez J, Tashima KT, et al. Efavirenz plus zidovudine and lamivudine, efavirenz plus indinavir, and indinavir plus zidovudine and lamivudine in the treatment of HIV-1 infection in adults. N Engl J Med 1999;341:1865-73.

5. Friis-Moller N, Sabin CA, Weber R, et al. Combination antiretroviral therapy and the risk of myocardial infarction. N Engl Med 2003;349:1993-2003. [Erratum, N Eng] J Med 2004;350:955.]

6. Mary-Krause M, Cotte L, Simon A Partisani M, Costagliola D. Increased risk of myocardial infarction with duration of protease inhibitor therapy in HIV-infected men. AIDS 2003;17:2479-86.

7. Holmberg SD, Moorman AC, William son JM, et al. Protease inhibitors and cardiovascular outcomes in patients with HIV-1. Lancet 2002;360:1747-8.

8. Iloeje UH, Yuan Y, L'Italien G, et al Protease inhibitor exposure and increased risk of cardiovascular disease in HIV infected patients. HIV Med 2005;6:37-44. 9. Mocroft A, Phillips AN, Friis-Moller N, et al. Response to antiretroviral therapy among patients exposed to three classes of antiretrovirals: results from the EuroSIDA study. Antivir Ther 2002;7:21-30. 10. Dieleman JP, Jambroes M, Gyssens IC, et al. Determinants of recurrent toxicitydriven switches of highly active antiretroviral therapy. AIDS 2002;16:737-45.

11. d'Arminio Monforte A, Lepri AC, Rezza $\mathrm{G}$, et al. Insights into the reasons for dis continuation of the first highly active antiretroviral therapy (HAART) regimen in a cohort of antiretroviral naive patients. AIDS 2000;14:499-507.
12. Friis-Moller N, Weber R, Reiss P, et al. Cardiovascular disease risk factors in HIV patients - association with antiretroviral therapy: results from the DAD study. AIDS 2003;17:1179-93.

13. Tunstall-Pedoe H, Kuulasmaa K, Amouyel P, Arveiler D, Rajakangas AM, Pajak A. Myocardial infarction and coronary deaths in the World Health Organization MONICA Project: registration procedures, event rates, and case-fatality rates in 38 populations from 21 countries in four continents. Circulation 1994;90:583-612. 14. WHO MONICA Project. MONICA manual, part IV: event registration. Geneva: World Health Organization, 1999. (Accessed March 29, 2007, at http://www.ktl. fi/publications/monica/manual/part4/iv-1. htm.)

15. van Leth F, Phanuphak P, Stroes E, et al. Nevirapine and efavirenz elicit different changes in lipid profiles in antiretroviral-therapy-naive patients infected with HIV-1. PLoS Med 2004;1:e19. [Erratum, PLoS Med 2004;1:e73.]

16. Fontas E, van Leth F, Sabin CA, et al. Lipid profiles in HIV-infected patients receiving combination antiretroviral therapy: are different antiretroviral drugs associated with different lipid profiles? J Infect Dis 2004;189:1056-74.

17. van der Valk M, Kastelein JJ, Murphy RL, et al. Nevirapine-containing antiretroviral therapy in HIV-1 infected patients results in an anti-atherogenic lipid profile. AIDS 2001;15:2407-14.

18. Zhou H, Pandak WM Jr, Lyall V, Natarajan R, Hylemon PB. HIV protease inhibitors activate the unfolded protein response in macrophages: implication for atherosclerosis and cardiovascular disease. Mol Pharmacol 2005;68:690-700.

19. Allred KF, Smart EJ, Wilson ME. Estrogen receptor-alpha mediates gender differences in atherosclerosis induced by HIV protease inhibitors. J Biol Chem 2006;281: 1419-25.

20. Sax PE, Kumar P. Tolerability and safety of HIV protease inhibitors in adults. J Acquir Immune Defic Syndr 2004;37: 1111-24. [Erratum, J Acquir Immune Defic Syndr 2004;37:1434.]

21. Saves M, Chene G, Ducimetiere P, et al. Risk factors for coronary heart disease in patients treated for human immunodeficiency virus infection compared with the general population. Clin Infect Dis 2003 37:292-8.

22. Pernerstorfer-Schoen H, Jilma B, Perschler A, et al. Sex differences in HAARTassociated dyslipidaemia. AIDS 2001;15: 725-34.

23. Currier JS, Taylor A, Boyd F, et al. Coronary heart disease in HIV-infected individuals. J Acquir Immune Defic Syndr 2003;33:506-12.

24. The Strategies for Management of Antiretroviral Therapy (SMART) Study Group. CD4+ count-guided interruption of antiretroviral treatment. N Engl J Med 2006; 355:2283-96.

25. Grunfeld C, Pang M, Doerrler W, Shigenaga JK, Jensen P, Feingold KR. Lipids, lipoproteins, triglyceride clearance, and cytokines in human immunodeficiency virus infection and the acquired immunodeficiency syndrome. J Clin Endocrinol Metab 1992;74:1045-52.

26. Constans J, Pellegrin JL, Peuchant E, et al. Plasma lipids in HIV-infected patients: a prospective study in 95 patients. Eur J Clin Invest 1994;24:416-20.

27. Riddler SA, Smit E, Cole SR, et al. Impact of HIV infection and HAART on serum lipids in men. JAMA 2003;289:297882.

28. Phillips AN, Carr A, Neuhaus J, et al. Interruption of ART and risk of cardiovascular disease: findings from SMART. Presented at the 14th Conference on Retroviruses and Opportunistic Infections, Los Angeles, February 26, 2007. abstract. (Accessed March 29, 2007, at http://www. retroconference.org/2007/abstracts/28863. htm.)

29. Sabin C, Morfeldt L, Friis-Møller N, et al. Changes over time in antiretroviral therapy (ART) use and risk factors for cardiovascular disease (CVD) in the D:A:D study. Presented at the 12th Conference on Retroviruses and Opportunistic Infections, Boston, February 25, 2005. abstract. (Accessed March 29, 2007, at http://www. retroconference.org/2005/cd/abstracts/ 25243.htm.)

Copyright (c) 2007 Massachusetts Medical Society. 